\title{
15. GRAIN SIZE CHANGES IN REWORKED PELAGIC SEDIMENTS, DEEP SEA DRILLING PROJECT SITE 5991
}

\author{
David K. Rea and Thomas R. Janecek, Department of Atmospheric and Oceanic Science, \\ The University of Michigan ${ }^{2}$
}

\begin{abstract}
Size analyses were performed on pelagic sediments from Core 599-3, which exhibited paleontologic and lithologic evidence of reworking. The results show that darker, transported layers above sharp contacts are $0.33 \phi$ coarser than the underlying lighter, in situ layers. The reworking is of unknown origin, but it coincides with periods of enhanced bottom currents and heightened tectonic activity during the latest Miocene.
\end{abstract}

\section{INTRODUCTION}

Clay-bearing and clayey nannofossil ooze recovered at DSDP Site 599 shows distinct light and dark layers tens of centimeters thick. Contacts between lower, lighter layers and overlying, darker layers are all sharp; contacts between dark layers and overlying lighter layers are either sharp or gradational. Changes in the preservation of microfossils and the intercalation of generally darker-colored sediments of nannofossil Zones CN8 and CN9a (8.1 to 9.2 and 6.7 to $8.1 \mathrm{Ma}$ ), with the generally lighter-colored sediments of Zone CN9b (5.4 to $6.7 \mathrm{Ma})$, with resulting age inversions and incomplete sequences (missing zones), all indicate significant reworking of these materials (Knüttel, this volume; Romine, this volume). In part to evaluate the argument for multiple episodes of reworking and local bottom transport and in part to satisfy simple scientific curiosity, 16 sediment samples were taken across five of the light-dark color changes in Core 599-3 to permit the determination of the grain size distribution in the bulk sediment. We hoped to demonstrate (1) size changes across the sharp color boundaries, which appeared to separate reworked and in situ sediment, and (2) size gradation within the apparently transported (darker) layers.

\section{BACKGROUND}

Few precise grain size analyses of bulk samples of pelagic sediment have been reported (among those published are Oser, 1972; van Andel, 1973; and Dowding, 1977). Sand-silt-clay percentages used to appear in the Initial Reports but do so no longer. Dauphin (1980) has determined the size of quartz grains isolated from North $\mathrm{Pa}$ cific sediments and related the data to depositional processes. We ourselves have reported size analyses of eolian grains extracted from pelagic sediments (Rea and Jane-

\footnotetext{
${ }^{1}$ Leinen, M., Rea, D. K., et al., Init. Repts. DSDP, 92: Washington (U.S. Govt. Printing Office).

2 Address: Oceanography Program, Department of Atmospheric and Oceanic Science, The University of Michigan, Ann Arbor, MI 48109; (Janecek, present address) Lamont-Doherty Geological Observatory, Palisades, NY 10964.
}

cek, 1982; Janecek and Rea, 1983). Those grains are usually 8.0 to $9.4 \phi$ in size and can be used to interpret some aspects of past atmospheric circulation. Ledbetter and his co-workers have published several papers that relate the grain size of the carbonate-free fraction of abyssal sediments to present and past deep-sea circulation. Antarctic Bottom Water flowing northward through the Vema Channel in the Rio Grande Rise is responsible for a coarsening from about 6.0 to $5.0 \phi$ of the carbonatefree fraction of the seafloor sediments in the channel axis (Ledbetter and Johnson, 1976). Downcore size analyses of the same sediment fraction show variations from 0.6 to $0.8 \phi$; the coarser sizes reflect more rapid currents (Ledbetter, 1979). Similar particle sizes for the carbonate-free fraction have been reported from the western Indian Ocean (Ellwood et al., 1979), and grain sizes of 6.2 to $7.0 \phi$ have been reported for this fraction for the Southern Ocean (Ledbetter, 1981; Allison and Ledbetter, 1982).

Postcruise analysis of Site 599 sediments (Knüttel, this volume) has demonstrated stratigraphic age inversions at 599-3-3, $21 \mathrm{~cm}$, where sediment of Zone CN9a (6.7 to $8.1 \mathrm{Ma}$ ) overlies material of Zone CN9b (5.4 to $6.7 \mathrm{Ma})$. The inversion is more extreme at $599-3-4,59 \mathrm{~cm}$, where ooze of Zone CN8 (8.1 to $9.2 \mathrm{Ma}$ ) overlies that of CN9b. Other age inversions occur in Section 599-2-4 between 122 and $147 \mathrm{~cm}$ (CN9a over CN9b), and within Section 599-3-2 (CN8 over CN9a). Our samples (Table 1, Fig. 1) cross the two inversions in Sections 599-3-3 and -4; the reworked sediments in Section 593-3-1 have an apparent zonal age of $\mathrm{CN} 8$.

\section{METHODS}

Seawater was added to sediment samples on board the Glomar Challenger to prevent dehydration and aggregation. The bulk, untreated sample was analyzed for grain size by Coulter Counter in May 1983, about $2 \mathrm{mo}$. after the samples were taken. An effort to repeat the analyses in December, $7 \mathrm{mo}$. later, revealed a large increase in the 8.0 to $10.0 \phi(4$ to $1 \mu \mathrm{m})$ fraction, presumably bacteria, so it was not possible to repeat the measurements. Future attempts at such an experiment should add fungicide to the seawater-sample slurry.

The Coulter Counter ZB results give the weight percent of the sample at $0.5 \phi$ intervals over the size range measured. From these data, median grain size ( $\phi_{50}$ of Folk, 1974) can be calculated; the precision of these values is $\pm 0.05 \phi$ (Rea and Janecek, 1982). 
Table 1. Grain size of sediments in Core 599-3.

\begin{tabular}{|c|c|c|c|c|}
\hline $\begin{array}{l}\text { Core-Section } \\
\text { (interval in } \mathrm{cm} \text { ) }\end{array}$ & $\begin{array}{l}\text { Sub-bottom } \\
\text { depth }(\mathrm{cm})\end{array}$ & $\begin{array}{l}\text { Median grain } \\
\text { size }(\phi)\end{array}$ & Color $^{\mathrm{a}}$ & $\begin{array}{l}\text { Boundary depth } \\
\text { in } \mathrm{cm} \text { below top } \\
\text { of section (cm } \\
\text { sub-bottom) }\end{array}$ \\
\hline $3-1,32-33$ & 1783 & 7.67 & \multirow{2}{*}{10 YR $4 / 4$} & \multirow{7}{*}{$41(1791)$} \\
\hline$\frac{3-1,37-38}{3-1,43-44}$ & $\begin{array}{l}1788 \\
1794\end{array}$ & $\begin{array}{l}7.36 \\
7.28\end{array}$ & & \\
\hline $3-1,49-50$ & 1800 & 7.20 & 7.5 YR $3 / 2$ & \\
\hline $3-1,61-62$ & 1812 & 7.53 & \multirow{2}{*}{7.5 YR 4/4 } & \\
\hline $3-1,71-72$ & 1822 & 7.58 & & \\
\hline $3-1,82-83$ & 1833 & 7.22 & \multirow{2}{*}{7.5 YR $3 / 2$} & \\
\hline $3-1,92-93$ & 1843 & 7.25 & & \\
\hline $3-3,3-4$ & 2054 & 7.12 & \multirow{2}{*}{7.5 YR $3 / 2$} & \multirow{4}{*}{21 (2071) } \\
\hline $3-3,18-19$ & 2069 & 6.99 & & \\
\hline $3-3,27-28$ & 2078 & 7.87 & \multirow{2}{*}{7.5 YR $4 / 4$} & \\
\hline $3-3,41-42$ & 2092 & 7.65 & & \\
\hline $3-4,47-48$ & 2248 & 7.29 & \multirow{2}{*}{$5 \mathrm{YR} 3 / 2$} & \multirow{4}{*}{59 (2259) } \\
\hline $3-4,57-58$ & 2258 & 7.35 & & \\
\hline $3-4,63-64$ & 2264 & 7.50 & \multirow{2}{*}{7.5 YR 4/4 } & \\
\hline $3-4,73-74$ & 2274 & 7.57 & & \\
\hline
\end{tabular}

a From Munsell soil color charts.

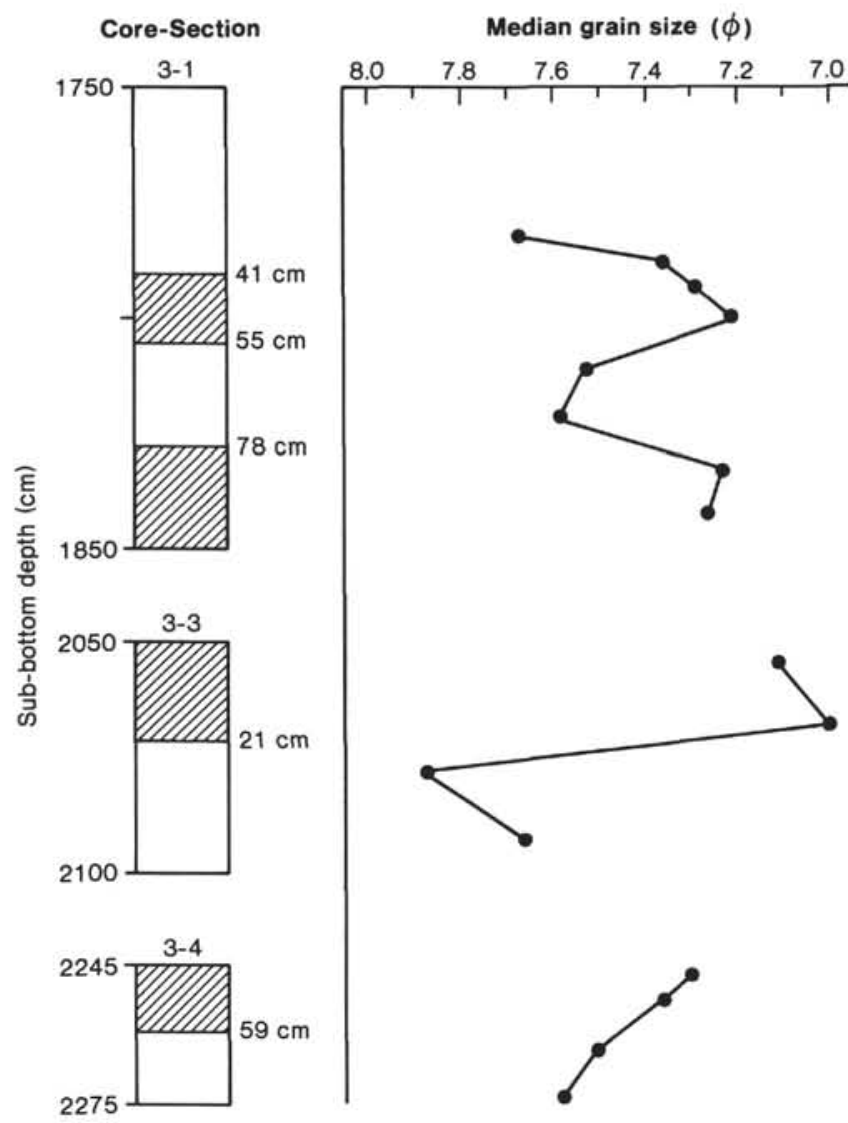

Figure 1. Color and median grain size of pelagic sediments in Core 599-3. Darker layers, indicated by shading, appear to be reworked.

\section{RESULTS}

Sediments exhibiting lithologic and paleontologic indications of reworking also show large changes in particle size across the layer boundaries. The darker-colored ooze, which is enriched in hydrothermal material (Site 599 chapter) and lies above the sharp contacts, is coarser grained than the lighter-colored ooze beneath (Fig. 1).
The size changes range from a minimum of $0.08 \phi$ at 599 $3-1,41 \mathrm{~cm}$, to a maximum of $0.88 \phi$ at $599-3-3,21 \mathrm{~cm}$. Other size changes average $0.28 \phi$ (Table 1). The largest fluctuation is two to three times as large, in terms of $\phi$ units, as the fluctuations in the carbonate-free silt fraction reported by Ledbetter (1981) as evidence of past bottom current fluctuation, although the average size changes are similar in the two studies.

We analyzed two samples from each layer to test for graded bedding; two of the four darker layers sampled may exhibit a fining-upward sequence, as may two of the lighter layers.

\section{DISCUSSION}

The data suggest that, in general, the younger, lightercolored, finer-grained oozes were deposited in situ and the older, darker, coarser units were displaced. When the drill sites for Leg 92 were selected, regions of rough topography were avoided to reduce the likelihood of downslope reworking, a strategy that apparently did not completely succeed. The site survey for Site 599 shows a region of low abyssal hills; the site itself lies at a water depth of $3654 \mathrm{~m}$ and is 1.5 to $2 \mathrm{~km}$ from a small hill $75 \mathrm{~m}$ high (Site 599 chapter).

The reworking at Site 599 occurred during the late Miocene $(5.4$ to $6.7 \mathrm{Ma})$. The latest Miocene was a time of major climatic change and involved polar cooling, a fall in sea level, the Messinian Crisis, and the carbon shift (Kennett, 1982). An increase in the formation and flow rates of bottom water resulted in an episode of sediment erosion in the Southern Ocean (Watkins and Kennett, 1971) that may have been most intense 7.2 to $6.2 \mathrm{Ma}$ (Ciesielski et al., 1982). Keller and Barron (1983) report increases in hiatus abundance at about 5 and $7 \mathrm{Ma}$. Sediments on the Blake Plateau record fluctuations in the intensity of the Gulf Stream; the strongest late Cenozoic acceleration of that current occurred 4.8 to $6.1 \mathrm{Ma}$ (Kaneps, 1979).

The reworking at DSDP Site 599 may be in response to the enhanced oceanic circulation during the late Miocene. The sediments from Zone CN9b at Site 598, which is $300 \mathrm{~m}$ deeper than Site 599 at $6 \mathrm{Ma}$ ( $3520 \mathrm{~m}$ versus $3200 \mathrm{~m}$; Rea and Leinen, this volume), show light and dark layers with gradational and mottled contacts and no obvious signs of being reworked, although reworking occurs in the older portions of the section recovered at Site 598. Thus, if general changes in abyssal circulation caused the reworking at Site 599, either currents were weaker at $3500 \mathrm{~m}$ than $3200 \mathrm{~m}$, or some additional effect, such as topographically enhanced flow at Site 599, must be invoked to explain the absence of coeval reworking at Site 598.

The major tectonic event of the late Cenozoic in the southeast Pacific was the series of three westerly axis jumps that formed the modern East Pacific Rise between 5 and $13^{\circ} \mathrm{S}$ (Rea, 1981). These jumps, which occurred between 8.2 and $5.7 \mathrm{Ma}$, and the resulting formation of new spreading centers and associated transform faults would create earthquakes that would be more frequent and probably larger in magnitude than those that occur 
now. The downslope transport of sediment from nearby low hills to Site 599 may have been triggered by these earthquakes.

\section{SUMMARY}

Reworking of pelagic sediment at DSDP Site 599 has resulted in sharp color and grain size differences between the younger, lighter, in situ, and darker, often older, transported layers (Fig. 1). The episode of reworking occurred during the latest Miocene, a time of globally enhanced bottom current activity and, possibly, of heightened regional seismicity.

\section{ACKNOWLEDGMENTS}

We thank Steve Knüttel for his careful biostratigraphic analysis of the reworked materials in Site 599. Mike Ledbetter reviewed this manuscript, and we thank him for his insights into these sorts of processes.

\section{REFERENCES}

Allison, E., and Ledbetter, M. T., 1982. Timing of bottom-water scour recorded by sedimentological parameters in the South Australian Basin. Mar. Geol., 46:131-147.

Ciesielski, P. F., Ledbetter, M. T., and Ellwood, B. B., 1982. The development of Antarctic glaciation and the Neogene paleoenvironment of Maurice Ewing Bank. Mar. Geol., 46:1-51.

Dauphin, J. P., 1980. Size distribution of chemically extracted quartz used to characterize fine-grained sediments. J. Sediment. Petrol., $50: 205-214$.

Dowding, L. G., 1977. Sediment dispersal within the Cocos Gap, Panama Basin. J. Sediment. Petrol., 47:1132-1156.

Ellwood, B. B., Ledbetter, M. T., and Johnson, D. A., 1979. Sedimentary fabric: a tool to delineate a high-velocity zone within a deep western Indian Ocean bottom current. Mar. Geol., 33:M51-M55.
Folk, R. L., 1974. Petrology of Sedimentary Rocks: Austin, TX (Hemphill).

Janecek, T. R., and Rea, D. K., 1983. Eolian deposition in the northeast Pacific Ocean: Cenozoic history of atmospheric circulation. Geol. Soc. Am. Bull., 94:730-738.

Kaneps, A. G., 1979. Gulf Stream: velocity changes during the late Cenozoic. Science, 204:297-301.

Keller, G., and Barron, J. A., 1983. Paleoceanographic implications of Miocene deep-sea hiatuses. Geol. Soc. Am. Bull., 94:590-613.

Kennett, J. P., 1982. Marine Geology: Englewood Cliffs, NJ (Prentice-Hall, Inc.).

Ledbetter, M. T., 1979. Fluctuations of Antarctic Bottom Water velocity in the Vema Channel during the last 160,000 years. Mar. Geol., 33:71-89.

, 1981. Paleoceanographic significance of bottom-current fluctuations in the Southern Ocean. Nature, 294:554-556.

Ledbetter, M. T., and Johnson, D. A., 1976. Increased transport of Antarctic Bottom Water in the Vema Channel during the last ice age. Science, 194:837-839.

Oser, R. K., 1972. Sedimentary components of Northwest Pacific pelagic sediments. J. Sediment. Petrol., 42:461-467.

Rea, D. K., 1981. Tectonics of the Nazca-Pacific divergent plate boundary. In Kulm, L. D., Dymond, J., Dasch, E. J., and Hussong, D. M. (Eds.), Nazca Plate: Crustal Formation and Andean Convergence. Geol. Soc. Am. Mem., 154:27-62.

Rea, D. K., and Janecek, T. R., 1982. Late Cenozoic changes in atmospheric circulation deduced from North Pacific eolian sediments. Mar. Geol. 49:149-167.

van Andel, T. H., 1973. Texture and dispersal of sediments in the Panama Basin. J. Geol., 81:434-457.

Watkins, N. D., and Kennett, J. P., 1971. Antarctic Bottom Water: major change in velocity during the late Cenozoic between Australia and Antarctica. Science, 173:813-818.

Date of Initial Receipt: 2 July 1984

Date of Acceptance: 26 December 1984 